\title{
STI571 (Glivec) induces cell death in the gastrointestinal stromal tumor cell line, GIST-T1, via endoplasmic reticulum stress response
}

\author{
HAJIME NAKATANI ${ }^{1}$, KEIJIRO ARAKI ${ }^{1}$, TOUFENG JIN ${ }^{1,3}$, MICHIYA KOBAYASHI $^{1}$, \\ TAKEKI SUGIMOTO $^{1}$, TOYOKAZU AKIMORI ${ }^{1}$, TSUTOMU NAMIKAWA ${ }^{1}$, KEN OKAMOTO $^{1}$, \\ TAKUMI NAKANO $^{1}$, TAKEHIRO OKABAYASHI $^{1}$, NORIHIRO HOKIMOTO $^{1}$, \\ HIROYUKI KITAGAWA ${ }^{1}$ and TAKAHIRO TAGUCHI ${ }^{2}$ \\ ${ }^{1}$ Department of Tumor Surgery, Kochi Medical School, Kochi University, Nankoku, Kochi 783-8505; \\ ${ }^{2}$ Department of Human and Medical Science, Graduate school of Kuroshio Science, Kochi University, \\ Nankoku, Kochi 783-8503, Japan; ${ }^{3}$ Department of General Surgery, College of Medical, \\ Yanbian University, 119 Juzijie, Yanjishi, Jilin Province, P.R. China
}

Received December 20, 2005; Accepted February 6, 2006

\begin{abstract}
STI571 is a specific inhibitor of tyrosine kinases, such as BCR-ABL, platelet-derived growth factor receptor, and c-KIT, and has recently been approved for the treatment of chronic myeloid leukemia and gastrointestinal stromal tumors (GISTs). This study demonstrated that STI571 induces cell death in the gastrointestinal stromal tumor cell line, GIST-T1. In these cells, STI571 induced pro-caspase-12 or pro-caspase- 7 cleavage and it affected caspase- 3 activity and induced the endoplasmic reticulum (ER)-resident chaperone, glucoseregulated protein 78 . The STI571-induced cell death was blocked by the protein synthesis inhibitor, cycloheximide. Together, these results suggest that STI571 induces cell death in GIST-T1 cells, at least in part, via the ER stress response.
\end{abstract}

\section{Introduction}

Stress conditions in cells up-regulate chaperone proteins and repress protein synthesis $(1,2)$. In the endoplasmic reticulum (ER), stress conditions induce a cellular defense mechanism referred to as the unfolded protein response (URP) $(1,2)$. One characteristic of this response is the induction of the ERresident chaperones, including the glucose-regulated proteins (GRPs) $(1,2)$. GRP78 increases protein folding in the ER lumen and is the best characterized of these proteins. It is up-regulated during the ER stress response, and when ER stress signals are unable to rescue cells, cell death pathways are activated. ER

Correspondence to: Dr Hajime Nakatani, Department of Tumor Surgery, Kochi Medical School, Nankoku, Kochi 783-8505, Japan

E-mail: nakatanh@med.kochi-u.ac.jp

Key words: gastrointestinal stromal tumor, c-KIT, STI571, GIST-T1, endoplasmic reticulum stress response stress is induced by exposure to tunicamycin and brefeldin A. Tunicamycin is a nucleoside antibiotic that inhibits $N$-linked glycosilation of target asparagine residues in the luminal domain proteins, whereas brefeldin A blocks the translocation of proteins from the ER to the Golgi aparatus by causing disassembly of the Golgi complex (3). The mechanism of cell death by ER stress remains incompletely elucidated; however, caspase-12 and -7 have been implicated in addition to the crucial effector caspase-3 (1-3).

Gastrointestinal stromal tumors (GISTs) are thought to be mesenchymal in origin, being derived from cells of the digestive tract. GISTs are characterized by the expression of both c-KIT and CD34 on the plasma membrane. Recent studies linked a mutation in $c$-kit to the process of oncogenic activation $(4,5)$. The $c$-kit proto-oncogene encodes for a tyrosine kinase receptor. Binding of the ligand, stem cell factor (SCF), activates the tyrosine kinase function of c-KIT, allowing it to transduce signals to the nucleus by phosphorylation of tyrosine residues in recruited signaling proteins. It is thought that deregulation of the tyrosine kinase activity is one of the principal mechanisms involved in abnormal cell growth and survival of malignant cells.

Recently, protein kinase inhibitors that disrupt these autonomous signaling loops have been developed for clinical use (6-12). STI571 was designated as an inhibitor of BCR/ABL, platelet-derived growth factor receptor (PDGFR), and c-KIT (13), and has been used successfully in unresectable or metastatic GIST patients with constitutive activation of c-KIT $(10,11)$.

In this study, we used the GIST-T1 cell line, which was established from a patient with metastatic GIST (14). To our knowledge, GIST-T1 is one of only two GIST cell lines that exist. GIST-T1 cells have a heterogenic $c$-kit mutation in exon 11 and c-KIT in GIST-T1 cells is constitutively activated $(14,15)$. We treated GIST-T1 cells with STI571 to assess the effects on cell growth and cell death, and the mechanisms by which such effects might be mediated. 


\section{Materials and methods}

Reagents. Dulbecco's modified Eagle's medium (DMEM) and antibiotics (penicillin, streptomycin) were purchased from Invitrogen Corporation (New York, USA). Anti-caspase-12 antibody, anti-caspase-7, and anti-GRP78 antibody were purchased from Santa Cruz Biotechnology, Inc. (CA, USA). Tunicamycin and brefeldin A were purchased from Wako (Osaka, Japan). The CPP32/caspase-3 colorimetric protease assay kit was purchased from Medical Biological Laboratories Co. Ltd. (Nagoya, Japan). Cycloheximide was purchased from Sigma (St. Louis, USA). STI571 (Glivec capsule, Novartis, Basel, Switzerland) was diluted in water to $5 \mu \mathrm{g} / \mu 1$ and stored at $-20^{\circ} \mathrm{C}$. Caspase-3 inhibitor (ApoAlert DEVD-CHO) was purchased from Clontech Laboratories (CA, USA).

Cells and cell culture. GIST-T1 cells were cultured in DMEM supplemented with penicillin, streptomycin, and $8 \%$ fetal bovine serum (FBS) maintained in a 95\% air, $5 \% \mathrm{CO}_{2}$ atmosphere at $37^{\circ} \mathrm{C}$ in a humidified incubator.

MTT assay to determine cell viability. In a 96-well plate, $1 \times 10^{6}$ cells $/ 100 \mu \mathrm{l}$ of cell suspension were used to seed each well. After $24 \mathrm{~h}$, reagents (STI571, brefeldin A, tunicamycin) were added in each well and cells were incubated for $24 \mathrm{~h}$. After a $24 \mathrm{~h}$ incubation with/without reagents, $10 \mu \mathrm{l}$ of a 2.5 $\mathrm{mg} / \mathrm{ml}$ solution in PBS of the MTT (3,-[4,5-dimethyl-thiazol-2yl]-2,5-diphenyl tetrazolium bromide; Sigma-Aldrich, Tokyo, Japan) was added in each well and incubated for $2 \mathrm{~h}$ at $37^{\circ} \mathrm{C}$. The resulting violet formazan precipitate was solubilized by the addition of $100 \mu \mathrm{l}$ of a $50 \% \mathrm{~N}, \mathrm{~N}$,-Dimethyl formamide/10\% SDS solution, and incubated for $4 \mathrm{~h}$ at room temperature. The plate was then analyzed on a plate reader at $570 \mathrm{~nm}$ to measure sample absorbance.

Flow cytometry. Cells $\left(1 \times 10^{6}\right)$ were seeded on a $6-\mathrm{cm}$ plate and incubated for $24 \mathrm{~h}$. Reagents were then added: STI571 $(1 \mu \mathrm{g} / \mathrm{ml})$, tunicamycin $(2 \mu \mathrm{g} / \mathrm{ml})$, or brefeldin A $(1 \mu \mathrm{M})$. To inhibit protein synthesis, cells were pre-treated with cyclohexmide $(100 \mu \mathrm{g} / \mathrm{ml})$ for $1 \mathrm{~h}$ before the addition of reagents. After $24 \mathrm{~h}$, both adherent and non-adherent cells were trypsinized and washed twice with ice-cold PBS and the cells were centrifuged at $500 \mathrm{x}$ g for $5 \mathrm{~min}$. Cells were treated with Annexin V-FITC Reagent (BioVision, Palo Alto, CA, USA) according to the manufacturer's protocol. Flow cytometry (FACscan, Becton Dickinson) was then used to determine the percentage of apoptotic cells with high FITC signal among 10000 events (using CellQuest software, Becton Dickinson).

Western blotting. Cells $\left(4 \times 10^{6}\right)$ were seeded on a $10-\mathrm{cm}$ dish for $24 \mathrm{~h}$ prior to the addition of reagents, STI571, brefeldin A, or tunicamycin in medium for a $24 \mathrm{~h}$ incubation. Cells were washed with PBS and lysed in RIPA buffer (Upstate Biotechnology Inc., NY, USA) containing $20 \mathrm{mM}$ sodium pyrophosphate, $20 \mathrm{mM} \mathrm{NaF}, 1 \mathrm{mM}$ orthovanadate, $2 \mathrm{mM}$ pyrophosphate, $1 \mathrm{mM}$ PMSF, $10 \mu \mathrm{g} / \mathrm{ml}$ aprotinin, and 10 $\mu \mathrm{g} / \mathrm{ml}$ leupeptin. Cell lysates containing comparable amounts of proteins, estimated by a Bradford assay (Bio-Rad, Munchen, Germany) were separated by SDS-PAGE and subjected to Western blotting.

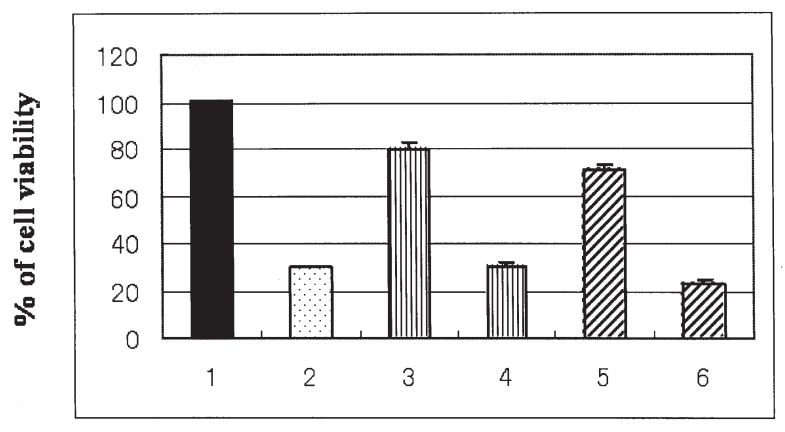

treatment

Figure 1. Cell viability was determined by MTT assay. Treatments: 1 , nontreated; 2, STI571 (1 $\mu \mathrm{g} / \mathrm{ml}) ; 3$, tunicamycin $(0.1 \mu \mathrm{g} / \mathrm{ml}) ; 4$, tunicamycin $(2 \mu \mathrm{g} / \mathrm{ml}) ; 5$, brefeldin A $(0.1 \mu \mathrm{M}) ; 6$, brefeldin A $(1 \mu \mathrm{M})$. The survival percentages are shown as the mean \pm standard deviation of triplicate experiments.

Determination of caspase-3 activity. Cells prepared as described for Western blotting were washed with PBS and lysed in the buffer supplied with the CPP32/caspase-3 colorimetric protease assay kit. The assay was carried out according to the manufacturer's protocol. The absorbance of each sample was measured at $405 \mathrm{~nm}$ on a plate reader.

\section{Results}

Assessment of cell viability by MTT assay. The cell viability of the GIST-T1 cells decreased in a dose-dependent manner following treatment with STI571 (15). At the concentration of $1 \mu \mathrm{g} / \mathrm{ml}$, STI571 reduced the viability to $30.1 \pm 0.5 \%$. Tunicamycin $(2 \mu \mathrm{g} / \mathrm{ml})$ and brefeldin $\mathrm{A}(1 \mu \mathrm{M})$ also affected the cell viability of the GIST-T1 cells $(30.2 \pm 1.5 \%$ and $23.5 \pm 1.0 \%$, respectively) (Fig. 1).

Determination of cell death. Both annexin V-and propidium iodide (PI)-positive cells represented necrotic or delayed-phase apoptotic cells (upper right quadrant). On the other hand, Annexin V-positive and PI-negative cells represented the early-phase apoptotic cells (lower right quadrant). STI571 (Fig. 2B), brefeldin A (Fig. 2C), and tunicamycin (Fig. 2D) induced mainly necrotic or delayed phase apoptotic cells following a $24 \mathrm{~h}$ incubation period $(15.8,27.3,20.6 \%$, respectively). Brefeldin $\mathrm{A}$ and tunicamycin are known to cause ER stress and induce cell death via the ER stress response $(1,16)$. In a previous study, Tinhofer et al reported that cycloheximide prevented cell death due to ER stress response (17). Cycloheximide is an inhibitor of protein synthesis, and it prevented excessive protein accumulation in the ER. Excessive protein accumulation in the ER caused cell death via ER stress response. Furthermore, we tested whether cycloheximide prevented cell death in the GIST-T1 caused by STI571 (Fig. 2F), tunicamycin (Fig. 2H), or brefeldin A (Fig. 2G). Cycloheximide did not induce cell death in the GIST-T1 cells, and it blocked the cell death caused by STI571, brefeldin A or tunicamycin treatment to levels of $5.5,8.4$, or $6.8 \%$, respectively.

GRP78 expression and cleavage of pro-caspase-12 or procaspase-7. Cells under stress conditions accumulate unfolded 

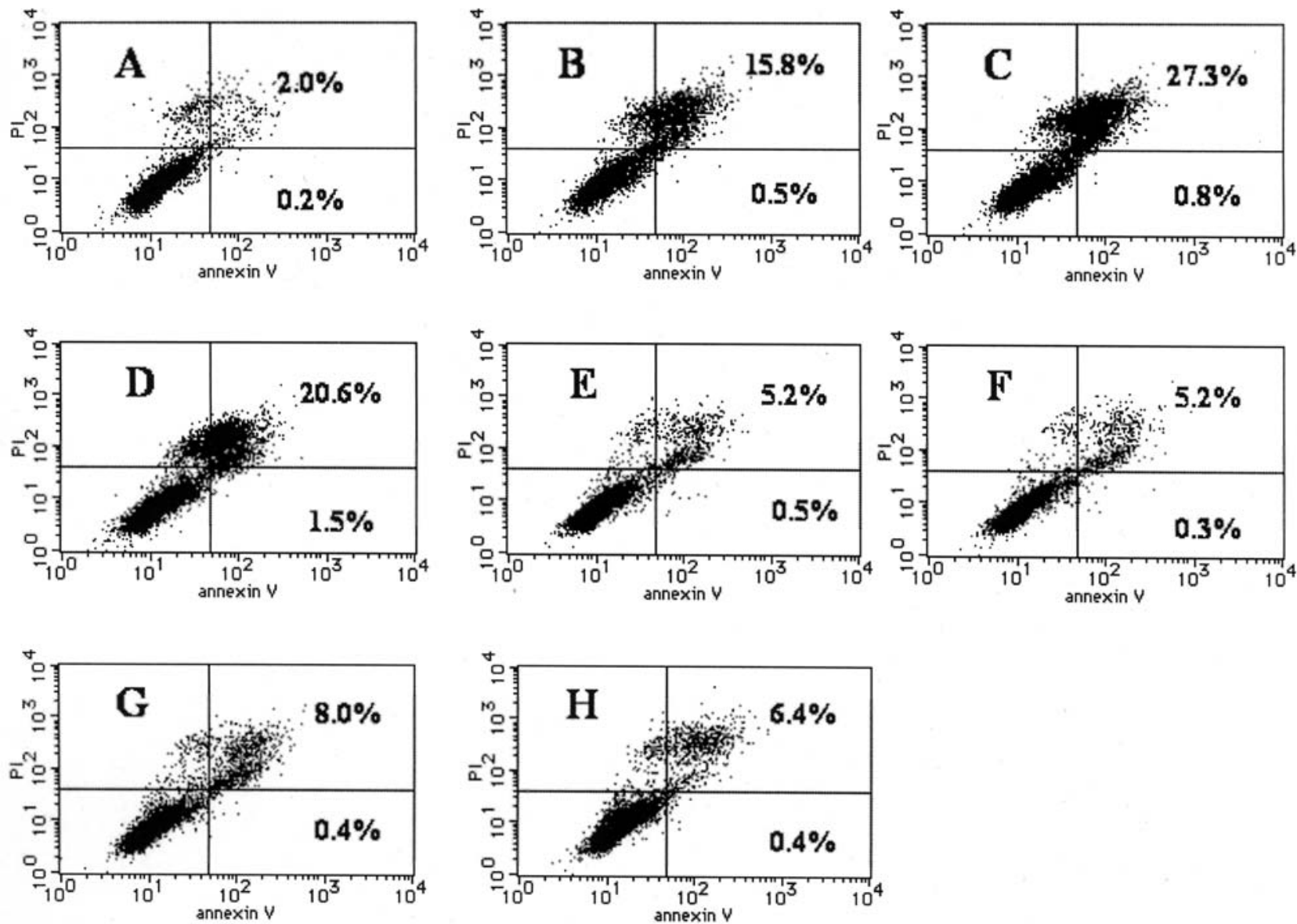

Figure 2. Cell death assay. Cells were treated with STI571, tunicamycin, or brefeldin A, with/without pre-treatment with $100 \mu \mathrm{g} / \mathrm{ml}$ of cycloheximide (CHX). A, non-treated; B, STI571 $(1 \mu \mathrm{g} / \mathrm{ml}) ; \mathrm{C}$, brefeldin A $(1 \mu \mathrm{M}) ; \mathrm{D}$, tunicamycin $(2 \mu \mathrm{g} / \mathrm{ml}) ; \mathrm{E}, \mathrm{CHX} ; \mathrm{F}, \mathrm{CHX}+\mathrm{STI} 571(1 \mu \mathrm{g} / \mathrm{ml}) ; \mathrm{G}, \mathrm{CHX}+\mathrm{brefeldin} \mathrm{A}(1 \mu \mathrm{M})$; $\mathrm{H}, \mathrm{CHX}+$ tunicamycin $(2 \mu \mathrm{g} / \mathrm{ml})$

$\mathbf{A}$

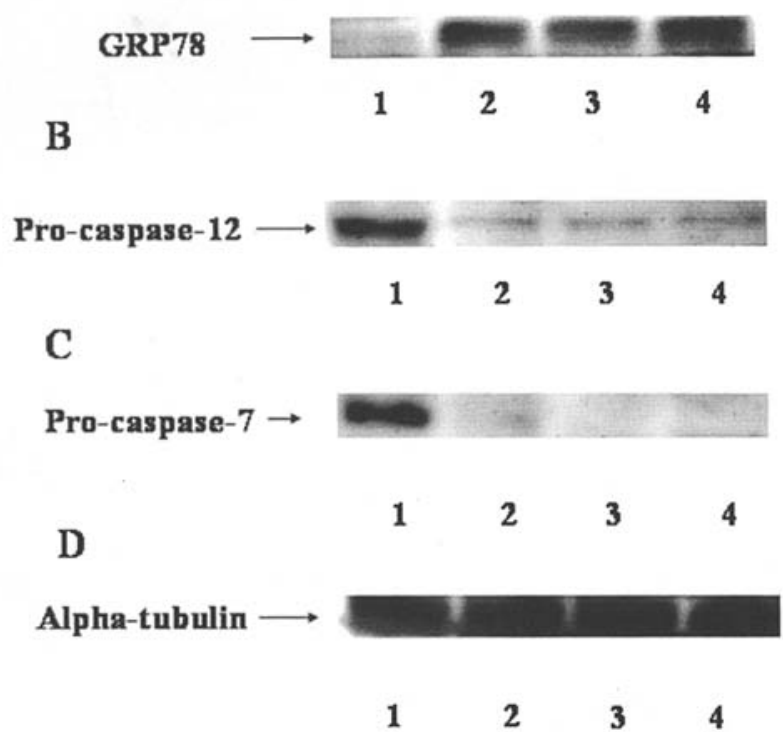

Figure 3. Determination of GRP78, pro-caspase-12, or pro-caspase-7 was determined by Western blot analysis. Cells were treated with STI571, brefeldin A, or tunicamycin for $24 \mathrm{~h}$. Lane 1, non-treated; 2, STI571 (1 $\mu \mathrm{g} /$ $\mathrm{ml}) ; 3$, brefeldin A (1 $\mu \mathrm{M}) ; 4$, tunicamycin $(5 \mu \mathrm{g} / \mathrm{ml})$. (A) Expression of GRP78, (B) cleavage of pro-caspase-12, (C) cleavage of pro-caspase-7, (D) expression of alpha-tubulin for control. Three independent experiments were done and similar results were obtained. protein response-induced ER-resident chaperones such as GRP78 $(1,2)$. GRP78 acts to protect the cells from stress; however, cells subjected to excessive stress undergo cell death via caspase-12, -7 and -3 activation $(1,2,16,18)$. In this study, Western blot analysis revealed that STI571, brefeldin A, and tunicamycin up-regulated the expression of GRP78 (Fig. 3A).

Furthermore, we investigated the expression and cleavage of caspase-12 or -7 . In this study, we used anti-mouse caspase-12 antibody for determination of caspase- 12 in the GIST-T1 cells. In a previous study, Hetz et al reported that anti-mouse caspase-12 antibodies could be detectable for human caspase-12 (18). Xie et al reported that pro-caspase12 was observed as a $60-\mathrm{kDa}$ band in the human liverderived Huh7 cell line (19). Pro-caspase-12 in the Huh7 cells was cleaved by reagent which induced ER stress (19). In our study, pro-caspase-12 in the GIST-T1 was detected as an $\sim 60-\mathrm{kDa}$ band and it was cleaved by treatment with STI571, brefeldin A, or tunicamycin (Fig. 3B). Pro-caspase-7 was also cleaved by STI571, brefeldin A, or tunicamycin (Fig. 3C).

Caspase-3 activity. In the cell death mechanism caused by ER stress response, caspase- 3 was activated followed by caspase- 12 and -7 activation $(16,18)$. Caspase- 3 is well known as a key molecule which is involved in the cell death pathway. Therefore, we assessed whether caspase- 3 was activated 


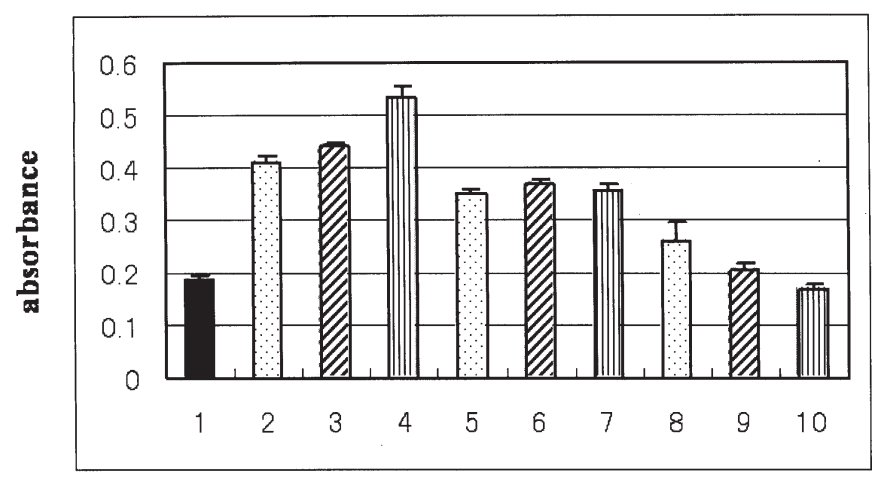

treatment

Figure 4. Caspase-3 activity. Caspase-3 activity was measured by using the CPP32/caspase-3 colometric protease assay kit, and the results were represented as absorbance. Treatment: 1, non-treated; 2, STI571 $(1 \mu \mathrm{g} / \mathrm{ml})$; 3 , brefeldin A $(1 \mu \mathrm{M}) ; 4$, tunicamycin $(5 \mu \mathrm{g} / \mathrm{ml}) ; 5$, cycloheximide $(\mathrm{CHX})+$ STI571 $(1 \mu \mathrm{g} / \mathrm{ml}) ; 6$, CHX + brefeldin A $(1 \mu \mathrm{M}) ; 7, \mathrm{CHX}+$ tunicamycin $(5 \mu \mathrm{g} / \mathrm{ml}) ; 8$, caspase-3 inhibitor $(10 \mu \mathrm{M})+$ STI571 $(1 \mu \mathrm{g} / \mathrm{ml}) ; 9$, caspase-3 inhibitor $(10 \mu \mathrm{M})+$ brefeldin $\mathrm{A}(1 \mu \mathrm{M}) ; 10$, caspase-3 inhibitor $(10 \mu \mathrm{M})+$ tunicamycin $(5 \mu \mathrm{g} / \mathrm{ml})$. The results are shown as the mean \pm standard deviation of triplicate experiments.

followed by ER stress response in the GIST-T1 cells. Caspase-3 activity was measured by using the CPP $32 /$ caspase- 3 colometric protease assay kit, and the results were represented as absorbance. STI571 led to caspase-3 activation (absorbance; 0.411 \pm 0.011 ). Tunicamycin, or brefeldin A also led to caspase- 3 activation (absorbance; $0.531 \pm 0.023$, $0.441 \pm 0.005$, respectively). Cycloheximide attenuated caspase- 3 activation by STI571, brefeldin A, or tunicamycin (absorbance; $0.348 \pm 0.01,0.355 \pm 0.01,0.367 \pm 0.011$, respectively). Caspase- 3 inhibitor also attenuated caspase- 3 activation by STI571, brefeldin A, or tunicamycin (absorbance; $0.259 \pm 0.035,0.204 \pm 0.013,0.168 \pm 0.011$, respectively). Absorbance of non-treated cells was $0.185 \pm 0.008$. STI571 as well as brefeldin A or tunicamycin activated caspase- 3 and cycloheximide attenuated the activation of caspae-3 induced by STI571, brefeldin A, or tunicamycin (Fig. 4).

\section{Discussion}

In our previous study, we demonstrated that STI571 inhibited the activation of c-KIT and reduced the cell viability in the gastrointestinal stromal tumor cell line, GIST-T1 (15). STI571 not only reduced cell proliferation but also induced cell death in GIST-T1 cells. The cell death mechanism which is induced by STI571 is not clear. It is very important to clarify the cell death mechanism which is induced by STI571 in GIST cells.

Recent studies revealed that endoplasmic reticulum stress response was one of the cell death mechanisms. Cells under stress conditions accumulate unfolded protein responseinduced ER-resident chaperones such as GRP78 $(1,2)$. GRP78 acts to protect the cells from stress; however, cells subjected to excessive stress undergo cell death via caspase-12, -7 , and -3 activation $(16,18,19)$. Brefeldin $\mathrm{A}$ and tunicamycin are known to cause ER stress and induce cell death via the ER stress response (3). In the GIST-T1 cells studied herein, STI571, brefeldin A and tunicamycin all markedly reduced cell viability and induced cell death, and blocking protein synthesis in these cells using cycloheximide prevented cell death induced by STI571, brefeldin A, or tunicamycin. Cycloheximide prevented excessive protein accumulation in the ER. These results suggested that STI571 induced cell death via ER stress response as well as tunicamycin or brefeldin A. The mechanism of cell death by ER stress remains incompletely elucidated; however, caspase-12 and -7 have been implicated in addition to the crucial effector caspase-3 (1-3). Next, we observed whether the expression of GRP78 and activation of caspase-12, -7 , or -3 by treatment with STI571, brefeldin A, or tunicamycin. STI571 induce the expression of GRP78 and activated caspase-12, -7, or -3. Cycloheximide or caspase- 3 inhibitor attenuated the activation of caspase-3 by treatment with STI571, brefeldin A, or tunicamycin. These results suggested that caspase- 3 was activated followed by caspase-7, caspase-12 with STI571, as well as brefeldin A or tunicamycin treatment. In our study, cisplatin which is well known as an anti-cancer reagent induced cell death of GIST-T1 at $10 \mu \mathrm{g} / \mathrm{ml}$ concentration, but cycloheximide could not prevent cell death induced by cisplatin (data not shown). Therefore, the STI571-induced cell death pathway was different from the cisplatin-induced one. Our previous study revealed that STI571 inhibited the activation of c-KIT in the GIST-T1 (15). Furthermore, we tested whether stem cell factor (SCF), c-KIT ligand, could rescue the cell death in the GIST-T1 cells. SCF could not rescue the cell death of GIST-T1 cells induced by STI571 (data not shown). STI571 completely inhibited the activation of c-KIT in the GIST-T1 cells even at stimulation with high concentration of SCF $(100 \mathrm{ng} / \mathrm{ml}$ ) (data not shown). STI571 did not induce cell death of another cancer cell line, such as DLD-1 (colon adenocarcinoma), MKN-45 (gastric cancer), SK-N-MC (neuroblastoma) (data not shown). These results indicated that activation of c-KIT played a crucial role in the survival signal in the GIST-T1 cells.

Taken together, STI571 inhibited activation of c-KIT and induced cell death of the GIST-T1 cells, at least in part, via ER stress response. Further studies are required to clarify the functions of molecules that modulate the cell death pathway, including mitochondrial cell death pathway induced by STI571 treatment.

\section{Acknowledgements}

We thank Ms. Motoko Miyata and Ms. Yuka Takezaki for their technical assistance.

\section{References}

1. Rao RV, Peel A, Logvinova A, Del Rio G, Hermel E, Yokota T, Goldsmith PC, Ellerby LM, Ellerby HM and Bredesen DE: Coupling endoplasmic reticulum stress to the cell death program: role of the ER chaperone GRP78. FEBS Lett 514: 122-128, 2002.

2. Reddy RK, Mao C, Baumeister P, Austin RC, Kaufman RJ and Lee AS: Endoplasmic reticulum chaperone protein GRP78 protects cells from apoptosis induced by topoisomerase inhibitors. J Biol Chem 278: 20915-20924, 2003.

3. Kogel D, Schomburg R, Schurmann T, Reimertz C, Konig HG, Poppe M, Eckert A, Muller WE and Prehn JH: The amyloid precursor protein protects PC12 cells against endoplasmic reticulum stress-induced apoptosis. J Neurochem 87: 248-256, 2003 
4. Hirota S, Isozaki K, Moriyama Y, Kanakura Y, Nishida T, Ishigro S, Kawano K, Hanada M, Kurata A, Takeda M, Tunio GM, Matsuzawa Y, Shinomura Y and Kitamura Y: Gainof-function mutation of $c$-kit in human gastrointestinal stromal tumors. Science 279: 577-580, 1998.

5. Kitamura Y, Hirota S and Nishida T: Gastrointestinal stromal tumors (GIST): a model for molecule-based diagnosis and treatment of solid tumors. Cancer Sci 94: 315-320, 2003.

6. Hirata A, Ogawa S, Kometani T, Kuwano T, Naito S, Kuwano M and Ono M: ZD1839 (Iressa) induces antiangiogenic effects through the inhibition of epidermal growth factor receptor tyrosine kinase. Cancer Res 62: 2554-2560, 2002.

7. Baselga J, Rischin D, Ranson M, Calvert H, Raymond E, Kieback DG, Kaye SB, Gianni L, Harris A, Averbuch SD, Bjork T, Feyereislova A, Swaisland H, Rojo F and Albanell J: Phase I safety, pharmacokinetic, and pharmacodynamic trial of ZD1839, a selective oral epidermal growth factor receptor tyrosine kinase inhibitor, in patients with five selected solid tumor types. J Clin Oncol 20: 4292-4302, 2002.

8. Yakes FM, Chinratanalab W, Ritter CA, King W, Seeling S and Arteaga CL: Herceptin-induced inhibition of phosphatidylinositol-3 kinase and Akt Is required for antibody-mediated effects on p27, cyclin D1, and antitumor action. Cancer Res 62: 4132-4141, 2002.

9. Bookman MA, Darcy KM, Clarke-Pearson D, Boothby RA and Horowitz IR: Evaluation of monoclonal humanized anti-HER2 antibody, trastuzumab, in patients with recurrent or refractory ovarian or primary peritoneal carcinoma with overexpression of HER2: a phase II trial of the Gynecologic Oncology Group. J Clin Oncol 21: 283-290, 2003.

10. Joensuu H, Roberts PJ, Sarlomo-Rikala M, Andersson LC, Tervahartiala P, Tuveson D, Silberman S, Capdeville R, Dimitrijevic S, Druker B and Demetri GD: Effect of the tyrosine kinase inhibitor STI571 in a patient with a metastatic gastrointestinal stromal tumor. N Engl J Med 344: 1052-1056, 2001.

11. Demetri GD, von Mehren M, Blanke CD, van den Abbeele AD, Eisenberg B, Roberts PJ, Heinrich MC, Tuveson DA, Singer S, Janicek M, Fletcher JA, Silverman SG, Silberman SL, Capdeville R, Kiese B, Peng B, Dimitrijevic S, Druker BJ, Corless C, Fletcher CD and Joensuu H: Efficacy and safety of imatinib mesylate in advanced gastrointestinal stromal tumors. N Engl J Med 347: 472-480, 2002.
12. Goldman JM and Melo JV: Targeting the BCR-ABL tyrosine kinase in chronic myeloid leukemia. N Engl J Med 344: 1084-1086, 2001

13. Heinrich MC, Griffith DJ, Druker BJ, Wait CL, Ott KA and Zigler AJ: Inhibition of c-kit receptor tyrosine kinase activity by STI571, a selective tyrosine kinase inhibitor. Blood 96: 925-932, 2000.

14. Taguchi T, Sonobe H, Toyonaga S, Yamasaki I, Shuin T, Takano A, Araki K, Akimaru K and Yuri K: Conventional and molecular cytogenetic characterization of a new human cell line, GIST-T1, established from gastrointestinal stromal tumor. Lab Invest 82: 663-665, 2002.

15. Nakatani H, Kobayashi M, Jin T, Tguchi T, Sugimoto T, Nakano T, Hamada S and Araki K: STI571 (Glivec) inhibits the interaction between c-KIT and heat shock protein 90 of the gastrointestinal stromal tumor cell line, GIST-T1. Cancer Sci 96: 116-119, 2005.

16. Hitomi J, Katayama T, Taniguchi M, Honda A, Imaizumi K and Toyama M: Apoptosis induced by endoplasmic reticulum stress depends on activation of caspase- 3 via caspase-12. Neurosci Lett 357: 127-130, 2003.

17. Tinhofer I, Anether G, Senfter M, Pfaller K, Bernhard D, Hara M and Greil R: Stressful death of T-ALL tumor cells after treatment with anti-tumor agent Tetrocarcin-A. FASEB J 10: $1295-1297,2002$

18. Hetz C, Russelakis-Carnerio M, Maundrell K, Castilla J and Sato C: Caspase-12 and endoplasmic reticulum stress mediate neurotoxicity of pathological prion protein. EMBO J 22: 5435-5445, 2003.

19. Xie Q, Khaoustov VI, Chung CC, Sohn J, Krishnan B, Lewis DE and Yoffe B: Effect of taurosodeoxycholic acid on endoplasmic reticulum stress-induced caspase-12 activation. Hepatology 36 : 592-601, 2002. 